\title{
A Study to Assess the Jaundice and Physiological Outcome in Neonates Receiving Phototherapy with White Sling Application around the Cradle in Selected Neonatal Intensive Care Units of Mangalore
}

\author{
A.Sagaya Arockia Mary \\ (M.Sc. Peadiatric Nursing, St. Ignatius Institute of Health Sciences ,India)
}

\begin{abstract}
Though phototherapy is extremely effective in bringing down the bilirubin levels in neonatal jaundice reflective effect of the white sling material around the phototherapy would enhance the reduction of jaundice. The aim of the study is to assess the effectiveness of white sling application around the phototherapy in the reduction of jaundice and physiological outcome in the healthy full term neonates. A quasi-experimental time series design was used and 40 neonates subjected to phototherapy were randomly assigned by lottery method to experimental (white sling around phototherapy) and control group (without white sling). The pre-intervention Mean serum bilirubin in experimental $(17.20+2.072)$, and in control group $(16.39+1.928)$. After $8^{\text {th }}$ and $24^{\text {th }}$ hours of phototherapy in the experimental group was declined $(3.085+1.03)(t=7.907, p<0.05)$ and $(6.415+$ $1.496 \mathrm{mg} / \mathrm{dl}),(t=5.985, p<0.05)$ while in the control group $(1.1140+.385)(t=7.907, p<0.05)$ and $(3.750+$ $1.314 \mathrm{mg} / \mathrm{dl})(t=5.985, p<0.05)$ respectively. The result shows a significant difference in the rate of reduction of serum bilirubin between the experimental and control group and it is one of the cost effective, non-invasive, non pharmacological management of neonates with non hemolytic jaundice.
\end{abstract}

Keywords: white sling application, physiological outcome, serum bilirubin, blanching of skin.

\section{Introduction}

Hyperbilirubinemia is the commonest morbidity in the neonatal period and $5-10 \%$ of all newborns require intervention. [1,2] Neonatal jaundice is estimated to occur in the majority of term infants $(60 \%)$ in the first week of life, and approximately $2 \%$ of infants reach total serum bilirubin (TSB) levels in excess of 20 $\mathrm{mg} / \mathrm{dL}[3]$ Hyperbilirubinemia can lead to a severe complication known as kernicterous. It has high morbidity and survivors of this pathology can present serious problem, like coreoathetosis, deafness and mental impairment.[1,2] Treatment is primarily focused on decreasing the bilirubin level and Phototherapy is a common and primary treatment in neonatal jaundice.[4,5] Studies have assessed the optimal wavelength of phototherapy light, the importance of irradiance and spectral power, and the types of light source, including the use of single versus multiple light sources. Outcome measures have been duration of need for phototherapy or rate of reduction of serum bilirubin over a given period of time. [6]

The effectiveness of phototherapy is related to the area of skin exposed, the radiant energy, and the wavelength of the light and the duration of exposure. The fall in bilirubin level is proportionately greater in the skin than in serum. Therefore, the infant receiving phototherapy should have as much as possible, skin exposed to the lights. [7]

The neonate is totally dependent and the early period of bonding between the mother and neonate is important. The neonatal jaundice and phototherapy might keep them separate, leading in increased cost and anxiety among parents. Phototherapy with simple white curtains hung at the sides of a phototherapy unit is more effective than phototherapy without curtains. This may translate into potential cost reduction in two ways. Firstly shorten the duration of treatment while the second by shorting the length of hospitalization. This would also mean considerably less separation from the mother and less interruption of breast feeding.

A randomised control clinical trial was conducted in 2006 July in Malaysia, on the efficacy of phototherapy for neonatal jaundice to see if it has been increased by the use of low-cost white reflecting curtains in all term newborns with uncomplicated neonatal jaundice (experimental group $n=50$ ) compared with single phototherapy without curtains (control group $\mathrm{n}=47$ ). The mean (standard deviation) decrease in total serum bilirubin levels after $4^{\text {th }}$ hourof phototherapy was significantly $(\mathrm{p}<0.001)$ higher in the study group $(27.62$ (25.24) $\mu \mathrm{mol} / \mathrm{l})$ than in the control group (4.04 (24.27) $\mu \mathrm{mol} / \mathrm{l})$. [8]

Keeping the above facts in mind, the present study is intended to increase the rate of reduction in serum bilirubin and to decrease the duration of phototherapy and positive physiological outcome by applying a white sling around the phototherapy cradle this is a cost effective intervention. This may result in early reduction of serum bilirubin and thus early discharge, promote parent-infant bonding. It decrease parental anxiety, financial constrain and other complications of prolonged phototherapy. 
A study to assess the jaundice and physiological outcome in neonates receiving phototherapy with ..

\section{Methodology}

A quasi-experimental time series design was used to assess the effectiveness of white sling application around the phototherapy in the reduction of jaundice and physiological outcome in the healthy full term neonates. The subjects were selected by purposive sampling technique and were assigned to experimental and control group by using a lottery method. The subjects assigned to experimental group were placed under phototherapy with white sling application that is made up of white plastic sheet with reflecting inner surface which is hung around three sides of double surface phototherapy cradle and left open on one side for uninterrupted observation and care of the neonates. The control group was placed in under double surface phototherapy cradle. Both groups were assessed the status of jaundice at the initiation, $8^{\text {th }}$ and $24^{\text {th }}$ hour of phototherapy by Serum total bilirubin, skin blanching Checklist and physiological status by Neonatal outcome scale.

\section{Results}

The analysis of the data shows, the speed of bilirubin reduction was slow in control group, when compared to the experimental group. In the experimental group the serum bilirubin level at pre-intervention was severe (mean 17.20+2.072), moderate at $8^{\text {th }}$ hour (mean $14.11+2.009$ ) and mild at $24^{\text {th }}$ hour (mean $10.78+1.608$ ) ( $A N O V A=270.580$ ) while in control group the serum bilirubin level at pre-intervention was severe $(16.390+1.928)$ and at $8^{\text {th }}$ hour continue to be severe (mean $\left.15.245+1.742\right)$ with mild reduction but only at $24^{\text {th }}$ hour it dropped to moderate level ( mean 12.635+0.948)(ANOVA=141.246) The rate of reduction of serum bilirubin in the experimental group at pre-intervention to $8^{\text {th }}$ hour was greater (mean 3.085 \pm 1.030 ) compared to control group $(1.140 \pm 0.386)(\mathrm{t}=7.907, \mathrm{p}<0.05)$; pre-intervention to $24^{\text {th }}$ hour in the experimental group was also greater $(6.415 \pm 1.496)$ when compared to the control group $(3.750 \pm 1.315)(t=5.985, \mathrm{p}<0.05) ; 8^{\text {th }}$ hour to $24^{\text {th }}$ hour in the experimental group was also greater $(3.330 \pm 1.125)$ when compared to the control group $(2.610 \pm 1.124)(\mathrm{t}=2.025, \mathrm{p}<0.05)$.

\section{Figures And Tables}

Table 1: ANOVA showing the effectiveness of white sling in the reduction of jaundice and improved physiological outcome of neonates in the experimental group

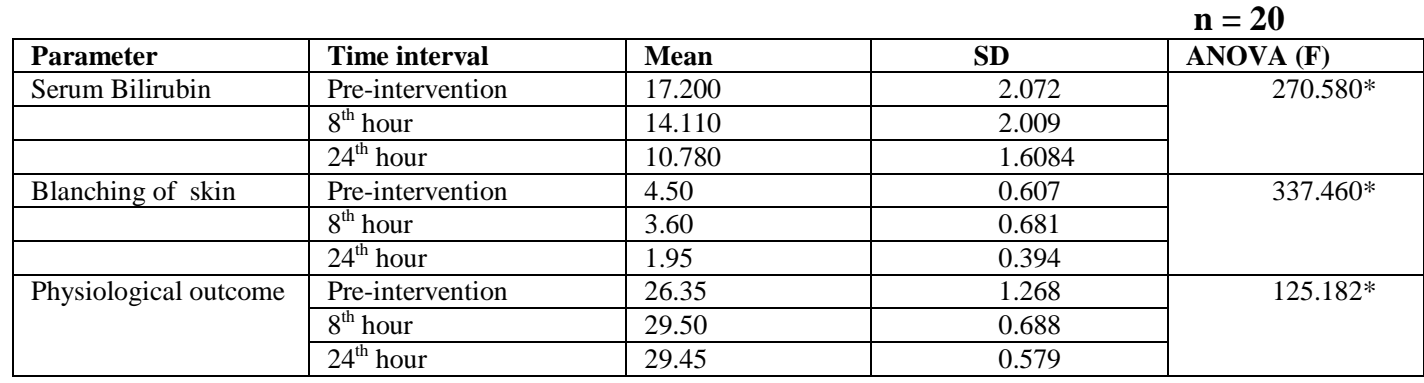

Table value of $\mathrm{ANOVA}=2.850$

* Significant

Table 2: Significance of difference in the reduction of jaundice and physiological outcome between the experimental and control groups

\begin{tabular}{|c|c|c|c|c|}
\hline & & \multicolumn{3}{|c|}{$n=20+20$} \\
\hline Parameter & Comparison & Group & Mean SD & 't' value \\
\hline \multirow{6}{*}{ Serum bilirubin } & Pre-intervention $-8^{\text {th }}$ hour & Experimental & $3.085 \quad 1.030$ & \multirow[t]{2}{*}{$7.907 *$} \\
\hline & & Control & 1.140 & \\
\hline & Pre-intervention $-24^{\text {th }}$ hour & Experimental & $\begin{array}{ll}6.415 & 1.496 \\
\end{array}$ & \multirow[t]{2}{*}{$5.985^{*}$} \\
\hline & & Control & 3.750 & \\
\hline & $8^{\text {th }}$ hour $-24^{\text {th }}$ hour & Experimental & 3.330 & \multirow[t]{2}{*}{$2.025^{*}$} \\
\hline & & Control & 2.610 & \\
\hline \multirow[t]{6}{*}{ Blanching skin } & Pre-intervention $-8^{\text {th }}$ hour & Experimental & 0.900 & \multirow[t]{2}{*}{$6.102 *$} \\
\hline & & Control & 0.200 & \\
\hline & Pre-intervention $-24^{\text {th }}$ hour & Experimental & 2.550 & \multirow[t]{2}{*}{$6.216^{*}$} \\
\hline & & Control & 1.450 & \\
\hline & $8^{\text {th }}$ hour $-24^{\text {th }}$ hour & Experimental & 1.650 & \multirow[t]{2}{*}{$2.430 *$} \\
\hline & & Control & 1.250 & \\
\hline \multirow{6}{*}{$\begin{array}{l}\text { Physiological } \\
\text { outcome }\end{array}$} & Pre-intervention $-8^{\text {th }}$ hour & Experimental & $-3.150 \quad 1.182$ & \multirow[t]{2}{*}{$2.029 *$} \\
\hline & & Control & $\begin{array}{ll}-2.350 & 1.309\end{array}$ & \\
\hline & Pre-intervention $-24^{\text {th }}$ hour & Experimental & $\begin{array}{ll}-3.100 & 1.210 \\
\end{array}$ & \multirow[t]{2}{*}{0.543} \\
\hline & & Control & $-2.900 \quad 1.119$ & \\
\hline & $8^{\text {th }}$ hour $-24^{\text {th }}$ hour & Experimental & $0.050 \quad 0.510$ & \multirow[t]{2}{*}{$2.009^{*}$} \\
\hline & & Control & $-0.550 \quad 1.234$ & \\
\hline
\end{tabular}

Table value $\mathrm{t}_{38}=1.690, \mathrm{P} \leq 0.05$

* Significant 


\section{Conclusion}

White sling application around the phototherapy cradle had a greater reduction of jaundice and improved physiological outcome and all neonates could be discharged within 24 hours phototherapy treatment with greater fall in serum bilirubin level. Early parent-child bond could be build up as well as cost of treatment could be reduced without the evidence of adverse effects. The sample size was small and irradiance of phototherapy was not measured.

A similar study could be conducted with randomization and selecting an equally comparable larger sample.Over the last two decades there has been a constant endeavor, to develop ways to increase the efficacy of phototherapy and at the same time reduce the side effects. Hanging White curtains around the phototherapy is an easy, effective and safe method, which can be routinely practiced in the treatment of neonatal jaundice.

\section{Acknowledgement}

This study has been undertaken under the constant guidance of Prof. Mrs. Prema D'souza, department of Pediatric Nursing Father Muller College of Nursing. I would like to place on record of gratitude and indebtedness for her support.

\section{References}

[1]. James EC, Samip K, Danielle K, Kelly B et al. An emergency medicine approach to neonatal hyperbilirubinemia. Emergency Medicine Clinics of North America, 25(4), 2007, 234-7.

[2]. Mohammad M, Ashkan, Narges P. The effect of low and moderate doses of clofibrate on serum bilirubin level in jaundiced term neonates. Paed Perinat Drug Ther, 8(2), 2007, 51-4.

[3]. Khalesi N, Rakhshani F, Zahedan I. Iran R. Knowledge, attitude and behavior of mothers on neonatal jaundice. J Pak Med Assoc, 58(12), 2008, 671-4

[4]. Mishra S, Agarwal R, Deorari AK, Paul VK. Jaundice in the newborns. Indian J Paediatr 75(2), 2008,157-63.

[5]. E. Richard, R.M Kliegman, B. Hal, Nelson's textbook of paediatrics (Philadelphia: W. B. Saunders Company; 2000).

[6]. Willy RH. Phototherapy for neonatal jaundice-Therapeutic effects on more than one level? Neonatal Update. 34(3), 2010,231-4.

[7]. Stokowski LA. Foundations in newborn care fundamentals of phototherapy for neonatal jaundice. Advances in Neonatal Care. 6(6) 2006,303-12.

[8]. Djokomuljanto S, Quah BS, Surini Y, Naraida R, Ismail NZN, Hansen TWR. Efficacy of phototherapy for neonatal jaundice is increased by the use of low-cost White reflecting curtains. Arch Dis Child Fetal Neonatal Ed. 91(6), 2006, 439-442. 